\title{
The role of proinflammatory cytokines on liver damage after pentylenetetrazole induced acute and chronic epilepsy models in rats
}

\section{Pentillentetrazol ille sıçanlarda oluşturulan akut ve kronik epilepsi modellerinde proinflamatuvar stokinlerin karaciğer hasarı üzerindeki rolü}

\author{
Engin Altinkaya, Hillmi A taseven
}

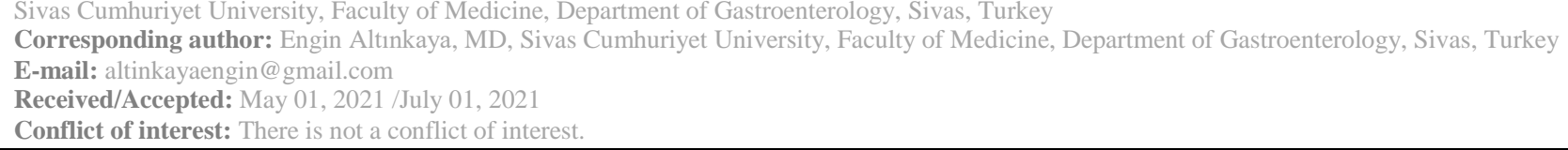

\section{SUMMARY}

Objective: The mechanisms of acute liver failure resulting from epilepsy are poorly defined and appear to be multifactorial, including hypoxia and steatosis. The role of inflammation on liver damage after seizures is unclear. This study aimed to investigate the relationship between proinflammatory cytokines and liver damage after pentylenetetrazole-induced acute and chronic epilepsy models in rats.

Method: Male Wistar albino adult rats $(\mathrm{n}=18)$, weighing $220-240 \mathrm{~g}$, were used in the experiment. The animals were divided into three groups: (1) Control Group (Control; $n=6$ ); rats were treated with a single dose of saline intraperitoneally (i.p.), (2) Acute Epileptic Model Group $(n=6)$; rats were treated with a single dose of i.p. PTZ (45 mg/kg), (3) Chronic Epileptic Model Group $(n=6)$; rats were treated with repeated doses of i.p. PTZ (35 $\mathrm{mg} / \mathrm{kg}$ ) every other day for 15 (fifteen) times.

Results: There was a significant difference between the control and acute epileptic model in terms of serum AST, TNF- $\alpha$, IL- $1 \beta$ and IL- 6 parameters $(p<0.05)$. On the other hand, there was a significant difference between the acute and chronic epileptic models in the serum AST, TNF- $\alpha$ and IL-6 parameters $(p<0.05)$.

Conclusions: As a result, while liver damage is secondary to hypoxia during epileptic seizures, multifactorial causes are blamed. Proinflammatory cytokines that increase in the liver after these factors may be responsible for liver damage in acute epileptic seizures. Compensation mechanisms such as antioxidant defense mechanism in chronic epileptic seizures may prevent liver damage.

Keywords: Epilepsy, liver injury, pentylenetetrazole, proinflammatory cytokine
Engin Altınkaya

Hilmi Ataseven

ORCID IDs of the authors: E.A. 0000-0001-6636-7073 H.A. 0000-0001-5458-509X 
Yöntem: Deneyde 220-240 gram ağırlığında erkek Wistar albino sıçanlar (n=18) kullanıldı. Hayvanlar üç gruba ayrıldı: (1) kontrol grubuna ( $\mathrm{s}=6$ ); intraperitoneal (i.p.) olarak çözücü olarak kullanılan salinverildi, (2) akut epileptik model grubuna (s=6) tek doz i.p. PTZ (45 mg/kg) uygulandı, (3) kronik epileptik model grubunda yer alan (s=6); sıçanlara ise gün aşırı ve tekrarlı olacak şekilde $15 \mathrm{kez}$ i.p. PTZ (35 mg/kg) olarak enjekte edildi.

Bulgular: Kontrol grubu ve akut epileptik model arasında serum AST, TNF- $\alpha$, IL-1 $\beta$ ve IL-6 parametreleri açısından anlamlı fark izlendi $(p<0.05)$. Bununla birlikte, akut ve kronik epileptik modelleri arasında serum AST, TNF- $\alpha$ ve IL-6 parametreleri yönünden anlamlı fark olduğu belirlendi $(p<0.05)$.

Sonuç: Sonuç olarak, epileptik nöbetler sırasında hipoksiye sekonder karaciğer hasarı izlenmekle birlikte, bu durumdan birçok faktör suçlanmaktadır. Akut epileptik nöbetlerden sonra karaciğerde artan proinflamatuar sitokinler, akut karaciğer hasarından sorumlu olabileceği düşünülmektedir. Kronik epileptik nöbetlerde ise muhtemel antioksidan savunma mekanizmalarının aktivasyonu ile karaciğer hasarını önleyebileceği ön görülmektedir.

Anahtar sözcükler: Epilepsi, karaciğer hasari, pentilentetrazol, proinflamatuvar sitokin

\section{INTRODUCTION}

Epilepsy, one of the most frequent neurodegenerative diseases, is a serious brain disorder characterized by repeated and unprovoked seizures and an important problem with about one in eleven persons experiencing at least once the seizure attack at some point in their lives ${ }^{1}$. It affects distinct population groups, such as children, adults. Epileptic seizures also cause excessive stress on the lungs, heart, and circulation and cause serious psychological, physical, and social consequences ${ }^{2,3}$. The mortality rates of patients with severe epilepsy are high in the general population ${ }^{4}$.

In innate immunity, the role of immune responses to the initiation of any injury, inflammation, and infection have prominently increased. ${ }^{5}$ In comparison to the acquired immune system, innate responses notch the instant and early phases of host defense against foreign microbes as well as to injury, originating the inflammatory reaction. These developments focus our reflection on be linked between cells of the innate immune system and the products of tissue damage and cell death. In an in vivo study, because of necrotic cell death, it produces an acute inflammatory response that resulting in further tissue damage and can cause disease conditions. This inflammatory response is induced by releasing proinflammatory intracellular components. ${ }^{5,6}$

The liver is among the issues that act as detoxification organs, protecting the body from dietary, environmental, and metabolic chemicals and toxins ${ }^{4}$. The mechanisms of acute liver failure resulting from epilepsy are poorly defined and appear to be multifactorial, including hypoxia and steatosis ${ }^{6,7}$. The role of inflammation on liver damage after seizures is unclear. This study aimed to investigate the relationship between proinflammatory cytokines and liver damage after pentylenetetrazole-induced acute and chronic epilepsy models in rats.

\section{MATERIAL AND METHODS}

Subjects: Male Wistar albino adult rats $(\mathrm{n}=18)$, weighing 220-240 g, were used in the experiment. Ethical approval was given by the Ethics Committee of Sivas Cumhuriyet University Faculty of Medicine. The animals were divided into three groups: (1) Control Group (Control; $\mathrm{n}=$ 6 ); rats were treated with a single dose of saline intraperitoneally (i.p.), (2) Acute Epileptic Model Group $(n=6)$; rats were treated with a single dose of i.p. PTZ (45 mg/kg), (3) Chronic Epileptic Model Group $(n=6)$; rats were treated with repeated doses of i.p. PTZ $(35 \mathrm{mg} / \mathrm{kg})$ every other day for 15(fifteen) times.

Seizure models: Acute epilepsy model is induced by single dose PTZ (45 mg/kg), and chronic epilepsy model is induced by $35 \mathrm{mg} / \mathrm{kg}$ PTZ with 15 injections. Following PTZ injections, rats were observed for convulsive activity for $30 \mathrm{~min}$. Activity occurred as generalized seizures, which started with the clonus of the facial and the forelimb muscles and continued with the neck and tail extensions, loss of straightening reflex with tonic flexion-extension and usually with extended colonic activities. Behavioral characteristics of seizures and duration of convulsions were recorded. Animals were sacrificed $24 \mathrm{~h}$. after PTZ induced seizure (single or last seizure) or saline administration.

Tissue assessment and methods: Before sacrificing, animals' blood was collected and centrifuged in $2000 \mathrm{rpm}$ at $20 \mathrm{~min}$, and serum samples were removed. Aspartate Aminotransferase (AST), Alanine Transaminase (ALT) and Alkaline Phosphatase (ALP) were measured in the serum sample by using an autoanalyzer at Sivas Cumhuriyet University Hospital. After this procedure, animals' liver tissues were 
removed and put into PBS five times more than tissue. All tissues were homogenized within this PBS on ice to avoid tissue degeneration by using a manual homogenizer. The samples were centrifuged in $3000 \mathrm{rpm}$ at $20 \mathrm{~min}$, and supernatants were separated. Tumor necrosis alpha $(\mathrm{TNF}-\alpha)$, interleukin-1 beta (IL-1 $\beta$ ) and interleukin-6 (IL-6) levels were measured in the liver supernatants according to the manufacturers' protocol by using the sandwich-ELISA method, and protein concentration was determined with a Bradford protein assay kit.

Statistics: All data were expressed as mean \pm standard error of mean (SEM). The SPSS 25.0 statistics package was used for all statistical analyses. Statistical comparisons were performed using analysis of variance (ANOVA) followed by post-ANOVA (Tukey's HSD) test to compare changes among individual groups. Differences between groups were statistically significant at $p<$ 0.05 .

\section{RESULTS}

\section{AST, ALT and ALP}

Serum AST, ALT, ALP, TNF- $\alpha$, IL- $1 \beta$ and IL-6 levels of all groups are presented in Table I. As shown in Table I there was a significant difference between the control and acute epileptic model in terms of serum AST, TNF- $\alpha$, IL- $1 \beta$ and IL- 6 parameters $(p<0.05)$. Additionally, there was a significant difference between the acute and chronic epileptic models in terms of serum AST, TNF- $\alpha$ and IL- 6 parameters $(p<0.05)$.

There was no significant difference between the groups in terms of serum ALT, ALP parameters $(p>0.05)$. There was no significant difference between the chronic epileptic model group and the control group ( $p>0.05$ ). Serum AST levels of the chronic epileptic model and the control group were significantly lower than the acute epileptic model group ( $p<0.05$ ). TNF- $\alpha$, IL-1 $\beta$ and IL-6 levels of the acute epileptic model group were significantly higher than the chronic epileptic model group and the control group $(p<0.05)$. TNF- $\alpha$ and IL-6 levels of the chronic group were significantly lower than the acute epileptic model group $(p<0.05)$ (Table 1$)$ (Figure 1).

Table 1: Serum AST, ALT and ALP levels in control, acute epileptic model and chronic epileptic model groups. Data are presented as mean $\pm \operatorname{SEM}(n=6)$.

\begin{tabular}{llcc}
\hline Groups & AST (U/L) & ALT (U/L) & ALP (U/L) \\
\hline Control & $111,98 \pm 9,46$ & $43,40 \pm 1,25$ & $145,16 \pm 8,53$ \\
Acute epileptic model & $202,14 \pm 15,46^{* * *}$ & $44,40 \pm 4,85$ & $161,83 \pm 12,87$ \\
Chronic epileptic model & $106,33 \pm 3,57^{\# \#}$ & $39,55 \pm 1,21$ & $155,16 \pm 12,37$ \\
\hline$* * * p<0.001$, compared to control group and ${ }^{\# \# \#} p<0.001$, compared to acute epileptic model group.
\end{tabular}



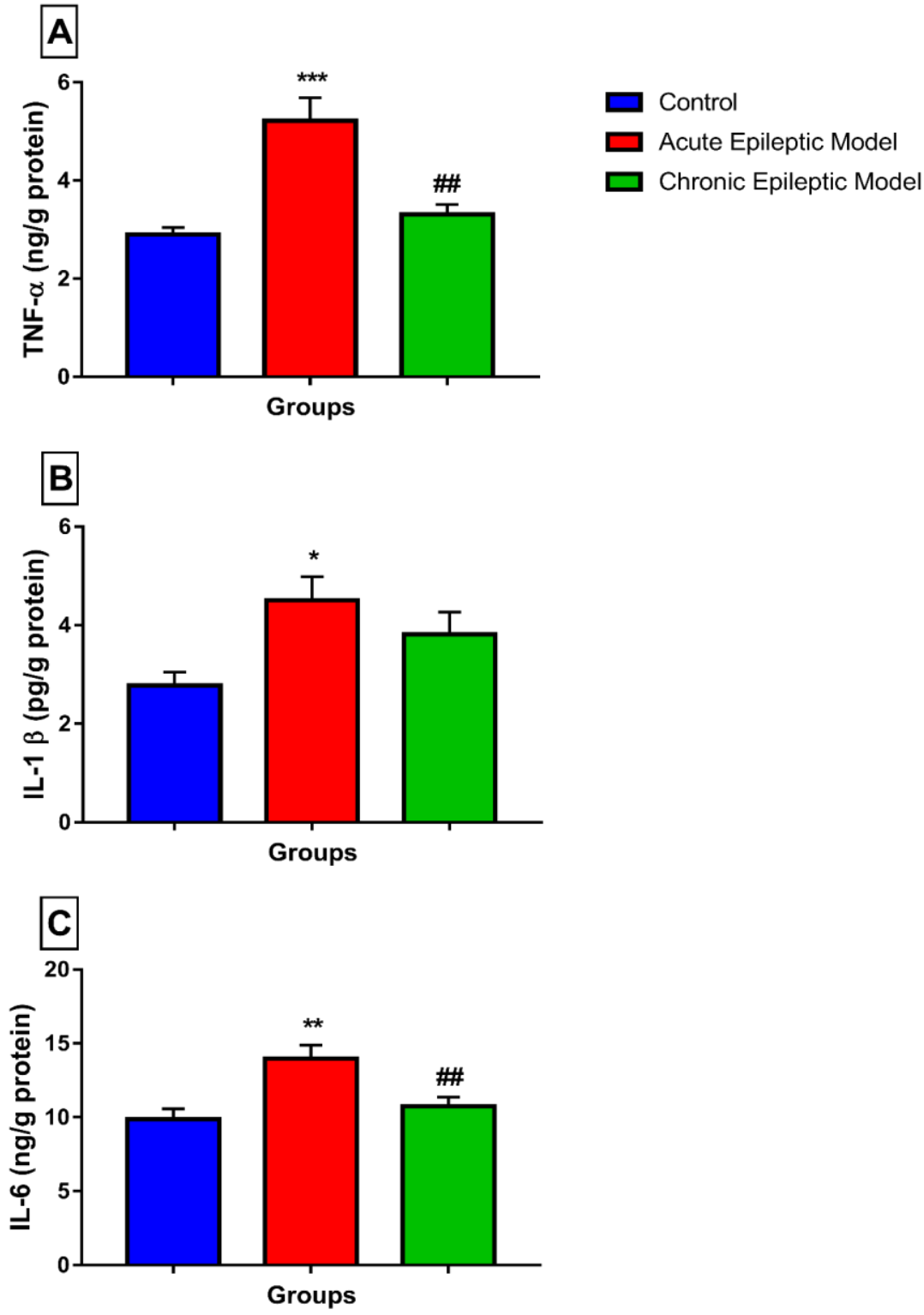

Figure 1 Liver: TNF- $\alpha$, IL-1 $\beta$ and IL-6 levels in control, acute epileptic model and chronic epileptic model groups. ${ }^{* * *} p<0.001,{ }^{* *} p<0.01,{ }^{*} p<0.05$, compared to control group and ${ }^{\# \#} p<0.01$, compared to acute epileptic model group.

\section{DISCUSSION}

Epilepsy is a serious neurological disorder characterized by seizures, it can also cause excessive stress not only in the central nervous system but also in the lungs, heart, and circulatory system. Depending on the balance between the stress caused by the seizure and the compensation mechanisms of the body, various levels of pathological damage can occur in the organs ${ }^{9}$. One of the most important affected organs is liver. There are cases when an acute liver failure occurs during epileptic seizures, and the liver transplantation is required ${ }^{7}$. It is thought that the cause of this liver failure during epileptic seizures is thought to be multifactorial due to the hypoxia, steatosis, and toxic effects of the drugs used, but the primary factor is hypoxia ${ }^{7}$. Our study determined liver enzymes levels to reveal possible damage to the liver during epileptic seizures. We found the aspartate aminotransferase levels, which reflects tissue hypoxia higher in the acute epileptic seizure group. The acute epileptic seizure group's AST levels were statistically higher than the control and chronic epileptic groups $(p<0.001)$. In the pertinent literature, several studies revealed a correlation between epilepsy and liver damage. For example, Nau KM et al. reported an increase in liver enzymes in patients with severe epileptic seizures ${ }^{10}$. Akbas $\mathrm{SH}$ et al. reported that lipid 
peroxidation as a result of oxidative stress caused hepatocyte damage ${ }^{11}$. Similarly, Aktaş A et al. reported that antioxidant defense mechanisms decreased more prominently, especially in rats with acute epileptic seizures, causing tissue damage more in this case [8]. In accordance with this literature information, in the current study, we found that, compared with the group having chronic epileptic seizures, the AST levels, which is an indicator of liver damage and more pronounced secondary to hypoxia, was increased in the group with acute epileptic seizures $(p<0.001)$.

Cytokines are regulatory peptides synthesized by nucleated cells. Many liver cells, such as Kupffer cell and stellate cell in the liver, synthesize both pro-inflammatory (IL-1b, IL-1a, IL-12, IL- 8, interferon, and TNF-a) and inflammatory (IL-1 receptor antagonists, soluble TNF receptors p55 and 75, IL-4 and IL-10) cytokines ${ }^{12,13}$. Cytokines cause necroinflammation in the liver by increasing the accumulation of fatty acids and inactivating cytochrome $\mathrm{P} 450$. In a healthy person, proinflammatory cytokines and anti-inflammatory cytokines are in balance. However, the case of liver damage, this balance shifts to the pro-inflammatory side ${ }^{12}$. Liver growth is tightly regulated by growth factors such as hepatocyte growth factor and epidermal growth factor, and cytokines such as interleukin 1 , interleukin 6 , and tumor necrosis factor-alpha. Akerman et al. showed that blocking TNF-a activity with an anti-TNF alpha antibody prevents liver regeneration ${ }^{14}$. Our study compared the groups in terms of TNF alpha, IL-1, and IL-6 cytokines in possible liver damage. We found that all three cytokines increased in the acute epileptic model groups compared to the control group. In terms of these cytokines, compared with the acute epileptic group and the chronic epileptic group, TNF alpha and IL-6 increased in the acute epileptic group and were statistically significant. $(p<0.05)$ Our study thought that damage to the liver in acute epileptic seizures may be due to pro-inflammatory cell increase in this group.

\section{CONCLUSION}

Taken together, while liver damage is secondary to hypoxia during epileptic seizures, multifactorial causes are blamed. Pro-inflammatory cytokines increase in the liver after these factors are responsible for liver damage in acute epileptic seizures. Compensation mechanisms such as antioxidant defense mechanisms in chronic epileptic seizures can prevent liver damage.

\section{REFERENCES}

1. B. L. Kroner, M. Fahimi, W. D. Gaillard, A.
Kenyon, and D. J. Thurman, "Epilepsy or seizure disorder? The effect of cultural and socioeconomic factors on self-reported prevalence," Epilepsy Behav., vol. 62, pp. 214217, Sep. 2016, doi: 10.1016/j.yebeh.2016.07.013.

2. A. W. Selassie, D. A. Wilson, G. U. Martz, G. G. Smith, J. L. Wagner, and B. B. Wannamaker, "Epilepsy beyond seizure: A population-based study of comorbidities," Epilepsy Res., vol. 108, no. 2, pp. 305-315, Feb. 2014, doi: 10.1016/j.eplepsyres.2013.12.002.

3. M. M. Acharya, B. Hattiangady, and A. K. Shetty, "Progress in neuroprotective strategies for preventing epilepsy," Progress in Neurobiology, vol. 84, no. 4. pp. 363-404, Apr. 2008, doi: 10.1016/j.pneurobio.2007.10.010.

4. C. Harden et al., "Practice guideline summary: Sudden unexpected death in epilepsy incidence rates and risk factors: Report of the guideline development, dissemination, and implementation subcommittee of the American Academy of Neurology and the American Epilepsy Society," Epilepsy Curr., vol. 17, no. 3, pp. 180-187, May 2017, doi: 10.5698/15357511.17.3.180.

5. Aristizábal B, González Á. Innate immune system. In: Anaya JM, Shoenfeld Y, Rojas Villarraga A, et al., editors. Autoimmunity: From Bench to Bedside. Bogota (Colombia): El Rosario University Press; 2013 Jul 18. Chapter 2.

6. David D. Chaplin J Allergy Clin Immunol. Author manuscript; available in PMC 2010 Aug 18. Published in final edited form as: J Allergy Clin Immunol. 2010 Feb; 125 (2 Suppl 2): S323. doi: 10.1016/j.jaci.2009.12.980

7. P. Ichai et al., "Fulminant hepatitis after grand mal seizures: Mechanisms and role of liver transplantation," Hepatology, vol. 38, no. 2, pp. 443-451, Aug. 2003, doi: 10.1053/jhep.2003.50327.

8. [8] A. Ahmet and S. Bilal, "Evaluation of Oxidative Stress Parameters in Liver in Pentylenetetrazole - Induced Acute and Chronic Epilepsy Model in Rats," Am J Biomed Sci Res, no. 6, pp. 2019-2024, doi: 10.34297/AJBSR.2019.05.000966.

9. Vercueil. L, "John Libbey Eurotext Epileptic Disorders Epilepsy and neurodegenerative diseases in adults: a clinical review," 2006. Epilepsy and neurodegenerative diseases in adults a clinical review 269372/article.phtml 
(accessed Feb. 20, 2020).

10. K. M. Nau, G. D. Divertie, A. K. Valentino, and W. D. Freeman, "Safety and efficacy of levetiracetam for critically Ill patients with seizures," Neurocrit. Care, vol. 11, no. 1, pp. 34-37, Aug. 2009, doi: 10.1007/s12028-0099185-0.

11. S. H. Akbas, A. Yegin, and T. Ozben, "Effect of pentylenetetrazol-induced epileptic seizure on the antioxidant enzyme activities, glutathione and lipid peroxidation levels in rat erythrocytes and liver tissues," Clin. Biochem., vol. 38, no. 11, pp. 1009-1014, Nov. 2005, doi: 10.1016/j.clinbiochem.2005.07.012.

12. H. Tilg and A. M. Diehl, "Cytokines in alcoholic and nonalcoholic steatohepatitis," New England Journal of Medicine, vol. 343, no. 20. pp. 1467-1467, Nov. 16, 2000, doi: 10.1056/NEJM200011163432007.

13. D. A. West et al., "Role for tumor necrosis factor $\alpha$ receptor 1 and interleukin-1 receptor in the suppression of mouse hepatocyte apoptosis by the peroxisome proliferator nafenopin," Hepatology, vol. 30, no. 6, pp. 1417-1424, Dec. 1999, doi: 10.1002/hep.510300612.

14. P. Akerman et al., "Antibodies to tumor necrosis factor- $\alpha$ inhibit liver regeneration after partial hepatectomy," Am. J. Physiol. Gastrointest. Liver Physiol., vol. 263, no. 4 264, 1992, doi: 10.1152/ajpgi.1992.263.4.g579. 